Check for updates

Cite this: RSC Adv., 2017, 7, 51986

Received 15th October 2017

Accepted 2nd November 2017

DOI: $10.1039 /$ c7ra11365j

rsc.li/rsc-advances

\section{A new seco-pimarane diterpene and four new $\beta$ - resorcylic acid lactones from a fungicolous Hypomyces subiculosus $\uparrow$}

\author{
Li Liu, $\neq^{\mathrm{ab}}$ Ruixing Liu,,$^{\mathrm{ab}}$ Buddha Bahadur Basnet, ${ }^{\mathrm{ac}}$ Li Bao, ${ }^{\mathrm{ab}}$ Junjie Han, ${ }^{\mathrm{ab}}$ \\ Jinwei Ren, ${ }^{\text {ab }}$ Zhaoqing Zeng, ${ }^{a}$ Wenying Zhuang ${ }^{a}$ and Hongwei Liu iD *ab
}

\begin{abstract}
One new pimarane diterpene (1) and four new $\beta$-resorcylic acid lactones (2-5), together with eight known compounds (6-13) were isolated from the solid culture of the fungicolous Hypomyces subiculosus. The structures of the new compounds were elucidated using extensive spectroscopic methods, including 1D and 2D NMR, HRESIMS, CD experiments, and chemical means. Compound 1 is a ring cleavage pimarane diterpene possessing a bicyclic ring system. All compounds were evaluated for cytotoxic activities. Only compound 7 showed moderate cytotoxicity against the $A 549$ cell line with an $I_{50}$ of $44.5 \mu \mathrm{M}$.
\end{abstract}

\section{Introduction}

Fungicolous fungi refer to a group of fungi growing on the mycelium or sporomes of other fungi as parasites, commensals or saprobes. ${ }^{1}$ They have been proven to be a rich source of new and biologically active natural products, with examples including lowdenic acid, ${ }^{2}$ thiersinines, ${ }^{3}$ solanapyrones, ${ }^{4}$ phomalevones, ${ }^{5}$ and botryolides. ${ }^{6}$ The fungi in the genus of Hypomyces are mycoparasitic and are distributed worldwide. Since the first report of sepedonin from Hypomyces in 1970, 26 natural products possessing diverse biological activities, such as antitumor, antibacterial, antimalarial, antifungal and hyperglycemic activities, have been identified from Hypomyces sp. ${ }^{8-10}$

In our search for new bioactive natural products from fungi, a fungicolous fungus of Hypomyces subiculosus obtained from Polyporus versicolor was chemically investigated. This fungus was fermented on rice and extracted with ethyl acetate to afford the organic solvent extract. A detailed chemical investigation on EtOAc extract led to the isolations of five new compounds, subiculosin A (1), aigialomycin $\mathrm{H}$ (2), aigialomycin I (3), paecilomycin $\mathrm{N}(4), 4^{\prime} R, 5^{\prime} R$-dihydroaigialospirol (5), together with eight known compounds, $7^{\prime}, 8^{\prime}$-dihydroaigialospirol (6), ${ }^{11}$ hypothemycin (7), ${ }^{12}$ dihydrohypothemycin $(8),{ }^{13}$ paecilomycin $\mathrm{J}$

\footnotetext{
${ }^{a}$ State Key Laboratory of Mycology, Institute of Microbiology, Chinese Academy of Sciences, No. 1 Beichenxi Road, Chaoyang District, Beijing 100101, People's Republic of China. E-mail: liuhw@im.ac.cn; Tel: +861064806076

${ }^{b}$ Savaid Medical School, University of Chinese Academy of Sciences, Beijing, 100049, People's Republic of China

'International College, University of Chinese Academy of Sciences, Beijing, 100049, People's Republic of China

$\dagger$ Electronic supplementary information (ESI) available: The NMR spectra of 1-5 and 14. See DOI: 10.1039/c7ra11365j

\$ These authors contributed equally to this work.
}

(9), ${ }^{14}$ paecilomycin L (10), ${ }^{14}$ aigialomycin D (11), ${ }^{13}$ blumenol C (12) ${ }^{15}$ 9-epi-blumenol $\mathrm{C}(\mathbf{1 3}) .{ }^{15}$ In this work, we reported the isolation, structural determination with the absolute stereochemistry, and bioactivity evaluation of these compounds (Fig. 1).

\section{Results and discussion}

\section{Structural elucidation}

Subiculosin A (1) was obtained as pale yellow power. Its molecular formula was determined to be $\mathrm{C}_{20} \mathrm{H}_{28} \mathrm{O}_{6}$ with 7 degrees of unsaturation by HRESIMS spectrum at $m / z[\mathrm{M}+\mathrm{H}]^{+}$ 365.1962. The ${ }^{1} \mathrm{H}$ NMR (Table 1 ) of 1 showed signals due to four olefinic protons $\left[\delta_{\mathrm{H}} 4.95(\mathrm{~m}, 2 \mathrm{H}), 5.90(\mathrm{dd}, J=17.5,10.9 \mathrm{~Hz})\right.$, $6.60 \mathrm{~s}$ ], three methylenes $\left[\delta_{\mathrm{H}} 1.81(\mathrm{dt}, J=10.1,2.9 \mathrm{~Hz}) ; 2.37(\mathrm{~d}\right.$, $J=3.1 \mathrm{~Hz}) ; 2.65$ (d, $J=12.5 \mathrm{~Hz}), 2.54(\mathrm{~d}, J=12.5 \mathrm{~Hz})]$, three methines [two oxygenated methines at $x_{\mathrm{H}} 3.69(\mathrm{dd}, J=10.1,6.2$ $\mathrm{Hz}), 4.23(\mathrm{t}, J=3.1 \mathrm{~Hz})$, respectively], and four methyl groups $\left[\delta_{\mathrm{H}}\right.$ $1.11(\mathrm{~s}), 1.17$ (s, 6H), 1.25 (s)]. The ${ }^{13} \mathrm{C}$ NMR of 1 exhibited twenty carbon resonances corresponding to three carbonyl carbons $\left(\delta_{\mathrm{C}}\right.$ $172.8,200.3,204.0)$, four olefinic carbons $\left(\delta_{\mathrm{C}} 112.9,142.6,146.0\right.$, 146.2), three $\mathrm{sp}^{3}$ quaternary carbons $\left(\delta_{\mathrm{C}} 39.0,40.8,56.2\right)$, three methine carbons $\left(\delta_{\mathrm{C}} 56.3,71.5,72.1\right)$ including two oxygenated methine carbons, three methylene carbons $\left(\delta_{\mathrm{C}} 34.0,37.5,44.2\right)$, and four methyl carbons $\left(\delta_{\mathrm{C}} 16.0,21.8,24.2,28.3\right)$. Extensive analysis of the ${ }^{1} \mathrm{H}-{ }^{1} \mathrm{H}$ COSY correlations of $\mathrm{H}-1-\mathrm{H}_{2}-2-\mathrm{H}-3$, together with the key $\mathrm{HMBC}$ correlations (Fig. 2) from $\mathrm{H}-1$ to C-3 and C-5, from $\mathrm{H}_{2}-2$ to $\mathrm{C}-4$ and C-10, from $\mathrm{H}-3$ to $\mathrm{C}-1$ and C-5, $\mathrm{H}-5$ to C-1, C-3, C-4, C-6, C-7, C-9, and C-10, from $\mathrm{H}-7$ to C-5, C-6, C-8, and C-9, from $\mathrm{H}_{3}-18(19)$ to C-3, C-4, and C-5, and from $\mathrm{H}_{3}$ 20 to C-1, C-5, C-9 and C-10 established 5,7-dihydroxy-4a,8,8trimethyl-4a,5,6,7,8,8a-hexahydronaphthalene-1,4-dione skeleton (Fig. 3). The side chain of 3-ethyl-3-methylpent-4-enoic acid was deduced by the ${ }^{1} \mathrm{H}^{-}{ }^{1} \mathrm{H}$ COSY correlation of $\mathrm{H}-15$ with $\mathrm{H}_{2}-16$, 

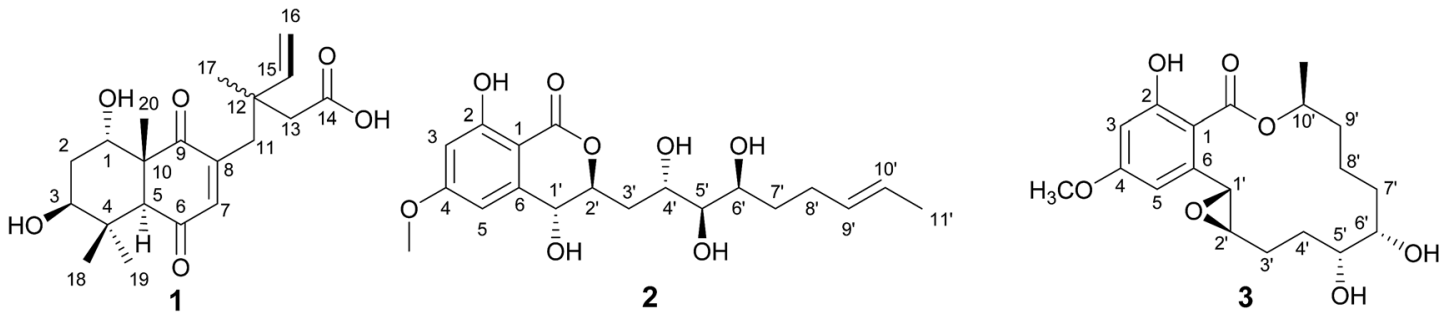
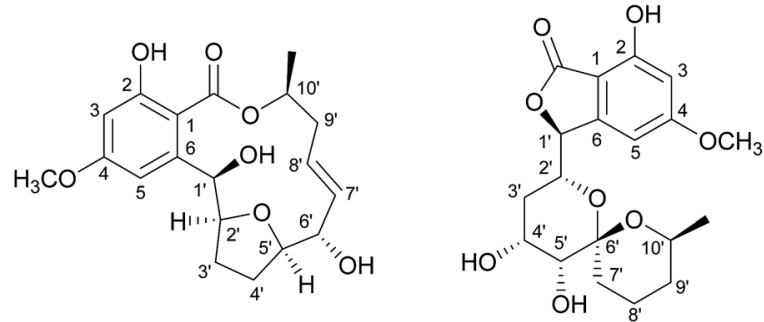<smiles>COc1cc(OC)cc([C@@H]2O[C@H]2C[C@@H](O)[C@H](O)C(=O)CCC[C@H](C)OC(=O)c2c(O)cc(OC)cc2O)c1</smiles><smiles>C[C@H](O)C/C=C/[C@@H](O)[C@H](O)CC/C=C/c1cc(O)cc(O)c1C(=O)O</smiles>

11
5<smiles>COc1ccc(C(=O)O[C@@H](C)CCCC[C@H](O)[C@H]2O[C@@H](CO)[C@H](O)C[C@H]2O)c(O)c1</smiles>

6<smiles>COc1cc(O)c2c(c1)[C@H]([C@H]1C[C@H](O)[C@@H](O)[C@]3(CCC[C@@H](C)O3)O1)OC2=O</smiles><smiles>[3H]C(CCC[C@@H](O)[C@H]1CC[C@@H]([C@H](O)c2cc(OC)cc(O)c2C(=O)OC)O1)OC</smiles><smiles>COc1cc(OC)cc([C@@H]2O[C@@H]2C[C@@H](O)[C@H](O)C(=O)/C=C\C[C@H](C)OC(=O)c2c(O)cc(OC)cc2O)c1</smiles>

10

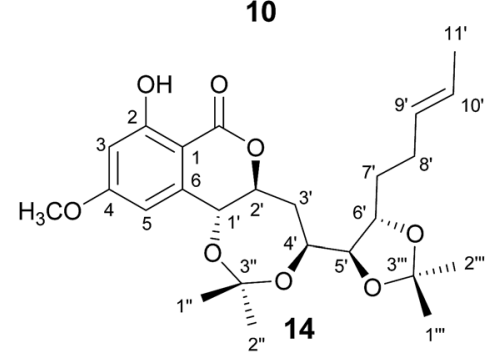

Fig. 1 Structures of compounds 1-14.

as well as the $\mathrm{HMBC}$ correlations from $\mathrm{H}_{2}-11$ to C-12, C-13, C-15, $\mathrm{C}-16$, and $\mathrm{C}-17$, from $\mathrm{H}_{2}-13$ to $\mathrm{C}-11, \mathrm{C}-12$, C-14, C-15, and C-17, from $\mathrm{H}_{3}-17$ to $\mathrm{C}-11, \mathrm{C}-12, \mathrm{C}-13$ and $\mathrm{C}-15$. The connection of this side chain with $\mathrm{C}-8$ was determined by $\mathrm{HMBC}$ correlations of $\mathrm{H}$ 7 with $\mathrm{C}-11$, and $\mathrm{H}_{2}-11$ with $\mathrm{C}-7, \mathrm{C}-8$, and C-9. The NOE correlations (Fig. 3) of $\mathrm{H}-3\left(\delta_{\mathrm{H}} 3.69\right)$ with $\mathrm{H}-5$ and $\mathrm{H}_{3}-19$ placed them on the same side. The NOE correlations of $\mathrm{H}-1\left(\delta_{\mathrm{H}} 4.23\right)$ with $\mathrm{H}_{3}$ 18 and $\mathrm{H}_{3}-20$ indicated that $\mathrm{H}-1, \mathrm{H}_{3}-18$ and $\mathrm{H}_{3}-20$ were on the other side of the rings. The absolute configuration of 1 was determined by applying the $\alpha, \beta$-unsaturated cyclohexanone octant rule. In the $\alpha, \beta$-unsaturated cyclohexanone octant rule, the conformation of cyclohexanone ring determines the hecility of enone moiety, which further establishes the sign of the Cotton effect. The positive Cotton effect (Fig. 4) deriving from $\mathrm{n}-\pi^{*}$ transition at $380 \mathrm{~nm}$ in 1 allowed the unambiguous assignment of the absolute configuration of $1 S, 3 S, 5 S, 10 R$ in 1. ${ }^{16,17}$ The absolute configuration at $\mathrm{C}-12$ in $\mathbf{1}$ was left unsolved in this work.

Aigialomycin $\mathrm{H}$ (2) possessed the molecular formula of $\mathrm{C}_{19} \mathrm{H}_{26} \mathrm{O}_{8}$ with 7 degrees of unsaturation based on HRESIMS and NMR data. Further analysis of its 1D NMR data (Table 2) and HSQC revealed an ester carbonyl group $\left(\delta_{\mathrm{C}} 168.1\right), a 1,2,3$, 5- tetrasubstituted benzene ring, a double bond $\left(\delta_{\mathrm{H}} 5.40, \delta_{\mathrm{C}}\right.$ $\left.124.2 ; \delta_{\mathrm{H}} 5.42, \delta_{\mathrm{C}} 131.5\right)$, five oxygenated methines $\left(\delta_{\mathrm{H}} 3.71, \delta_{\mathrm{C}}\right.$ $65.9 ; \delta_{\mathrm{H}} 4.52, \delta_{\mathrm{C}} 66.7 ; \delta_{\mathrm{H}} 3.64, \delta_{\mathrm{C}} 68.7 ; \delta_{\mathrm{H}} 2.96, \delta_{\mathrm{C}} 76.1 ; \delta_{\mathrm{H}} 4.60$, $\left.\delta_{\mathrm{C}} 80.3\right)$, three methylenes $\left(\delta_{\mathrm{H}} 2.05,1.96, \delta_{\mathrm{C}} 28.7 ; \delta_{\mathrm{H}} 1.90,1.69\right.$, $\left.\delta_{\mathrm{C}} 36.1 ; \delta_{\mathrm{H}} 1.47,1.40, \delta_{\mathrm{C}} 33.5\right)$, a doublet methyl $\left[\delta_{\mathrm{H}} 1.60(\mathrm{~d}, J=\right.$ $\left.4.8 \mathrm{~Hz}), \delta_{\mathrm{C}} 17.8\right]$, a methoxy group $\left(\delta_{\mathrm{H}} 3.83, \delta_{\mathrm{C}} 55.8\right)$ and five exchangeable hydrogens $\left[\delta_{\mathrm{H}} 4.05(\mathrm{~d}, J=7.0), 4.29(\mathrm{~d}, J=7.4)\right.$, $4.76(\mathrm{~d}, J=6.4), 6.04(\mathrm{~d}, J=6.2), 11.12(\mathrm{~s})]$. The HMBC correlations from $\mathrm{H}-3$ to $\mathrm{C}-1, \mathrm{C}-2, \mathrm{C}-4$, and $\mathrm{C}-5$, from $\mathrm{H}-5$ to $\mathrm{C}-1, \mathrm{C}-3$, $\mathrm{C}-4$, and $\mathrm{C}-6$, and from $\mathrm{CH}_{3} \mathrm{O}-4$ to $\mathrm{C}-4$ revealed the substructure moiety of 3-methoxyphenol (Fig. 2). The side chain structure from $\mathrm{C}-1^{\prime}$ to $\mathrm{C}-11^{\prime}$ was established primarily by COSY correlations of $\mathrm{H}-1^{\prime}-\mathrm{H}-2^{\prime}-\mathrm{H}_{2}-3^{\prime}-\mathrm{H}-4^{\prime}-\mathrm{H}-5^{\prime}-\mathrm{H}-6^{\prime}-\mathrm{H}_{2}-7^{\prime}-\mathrm{H}_{2}-8^{\prime}-\mathrm{H}-9^{\prime}-\mathrm{H}-$ $10^{\prime}-\mathrm{H}_{3}-11^{\prime}, \mathrm{OH}-1^{\prime}-\mathrm{H}-1^{\prime}, \mathrm{OH}-4^{\prime}-\mathrm{H}-4^{\prime}, \mathrm{OH}-5^{\prime}-\mathrm{H}-5^{\prime}$, and $\mathrm{OH}-6^{\prime}-\mathrm{H}-$ $6^{\prime}$. The connection of $\mathrm{C}-1^{\prime}$ and C-6 was elucidated by HMBC correlations from $\mathrm{H}-\mathbf{1}^{\prime}$ to $\mathrm{C}-1, \mathrm{C}-5$, and $\mathrm{C}-6$. Considering a remaining unsaturation and the chemical shift of $\mathrm{C}-2^{\prime}$ $\left(\delta_{\mathrm{C}} 80.3\right)$, as well as the HMBC correlations from $\mathrm{H}-2^{\prime}\left(\delta_{\mathrm{H}} 4.60\right)$ to the ester carbonyl group $\left(\delta_{\mathrm{C}} 168.1\right), \mathrm{C}-2^{\prime}$ was determined to connect with carbonyl carbon via an oxygen atom to form 
Table $1{ }^{1} \mathrm{H}(500 \mathrm{MHz})$ and ${ }^{13} \mathrm{C}$ NMR $(125 \mathrm{MHz})$ data of 1 in acetone- $d_{6}$

\begin{tabular}{lrl}
\hline No. & \multicolumn{1}{c}{$\delta_{\mathrm{C}}$} & $\delta_{\mathrm{H}}($ mult. $J$ in Hz) \\
\hline 1 & 71.5 & $4.23, \mathrm{t}(3.1)$ \\
2 & 34.0 & $1.81, \mathrm{dt}(10.1,2.9)$ \\
3 & 72.1 & $3.69, \mathrm{dd}(10.1,6.2)$ \\
4 & 39.0 & \\
5 & 56.3 & $3.27, \mathrm{~s}$ \\
6 & 200.3 & \\
7 & 142.6 & $6.60, \mathrm{~s}$ \\
8 & 146.2 & \\
9 & 204.0 & \\
10 & 56.2 & $2.65, \mathrm{~d}(12.5)$ \\
11 & 37.5 & \\
& & $2.37, \mathrm{~d}(3.1)$ \\
12 & 40.8 & \\
13 & 44.2 & $5.90, \mathrm{dd}(17.5,10.9)$ \\
14 & 172.8 & $1.95, \mathrm{~m}$ \\
15 & 146.0 & $1.17, \mathrm{~s}$ \\
16 & 112.9 & $1.25, \mathrm{~s}$ \\
17 & 24.2 & $1.17, \mathrm{~s}$ \\
18 & 16.0 &
\end{tabular}

a $\delta$-lactone. The trans-double bond between $\mathrm{C}-9^{\prime}$ and $\mathrm{C}-10^{\prime}$ was ascertained by the NOE correlation of $\mathrm{H}_{3}-11^{\prime}$ with $\mathrm{H}-9^{\prime}$. The stereochemistry of 2 was deduced by analysis of coupling constant values and conversion to acetonide derivatives as previous reported for aigialomycin $\mathrm{F} .{ }^{11}$ The ${ }^{1} \mathrm{H}-{ }^{1} \mathrm{H} J_{1^{\prime}, 2^{\prime}}$ value of $6.6 \mathrm{~Hz}$ indicated a trans relation of these protons. Treatment of 2 with 2, 2-DMP in the presence of $\mathrm{TsOH}$ ( $\mathrm{rt}, 4 \mathrm{~h}$ ) gave a bisacetonide derivative $\mathbf{1 4}$ as the sole product (Scheme 1). Compound 14 was determined to possess the molecular formula of $\mathrm{C}_{25} \mathrm{H}_{34} \mathrm{O}_{8}$ by HRESIMS at $m / z[\mathrm{M}+\mathrm{H}]^{+} 463.2335$, thus indicating two more $\mathrm{C}_{3} \mathrm{H}_{6}$ units than that of 2. The HMBC correlations from $\mathrm{H}-1^{\prime}\left(\delta_{\mathrm{H}} 5.05\right)$ and $\mathrm{H}-4^{\prime}\left(\delta_{\mathrm{H}} 3.90\right)$ to $\mathrm{C}-3^{\prime \prime}\left(\delta_{\mathrm{C}}\right.$ 101.7) revealed the seven-membered acetonide moiety in 14.
Although the HMBC corresponding signals between $\mathrm{H}-5^{\prime}\left(6^{\prime}\right)$ and $\mathrm{C}-3^{\prime \prime \prime}$ were not observed, another $\mathrm{C}_{3} \mathrm{H}_{6}$ unit was most likely to be linked with $\mathrm{C}-5^{\prime}$ and $\mathrm{C}-6^{\prime}$ via oxygen by considering the chemical shifts of $\mathrm{C}^{\prime} 5^{\prime}\left(\delta_{\mathrm{C}} 81.6\right)$ and C-6 $6^{\prime}\left(\delta_{\mathrm{C}}\right.$ 67.9). The NOE correlation (Fig. 3) of $\mathrm{H}-4^{\prime}\left(\delta_{\mathrm{H}} 3.90\right)$ with $\mathrm{H}-2^{\prime}\left(\delta_{\mathrm{H}} 4.45\right)$ placed them on the same side of the seven membered-ring. The vicinal coupling constants $\left({ }^{3} J_{4^{\prime}, 5^{\prime}}=7.1 \mathrm{~Hz}\right)$ between $\mathrm{H}-4^{\prime}$ and $\mathrm{H}-5^{\prime}$ implied a trans relation of them. The Dana's method could be applied to assign the relative configuration of the 1,2-diols via their 1,2-dioxolanes. In the 1,2-diol acetonides, the chemical shifts of methyl carbons for 1,2-anti configuration were at about $25 \mathrm{ppm}\left(\mathrm{Me}_{\beta}\right)$ and $28 \mathrm{ppm}\left(\mathrm{Me}_{\alpha}\right)$; for 1,2-syn configuration, both of the chemical shifts were at about 27 ppm. ${ }^{18-20}$ Hence, 1,2diols at C5/C6 position in 2 was determined to adopt the 1,2-syn based on the ${ }^{13} \mathrm{C}$ NMR signals of $\mathrm{C}-1^{\prime \prime \prime}\left(\delta_{\mathrm{C}} 27.4\right)$ and $\mathrm{C}-2^{\prime \prime \prime}$ $\left(\delta_{\mathrm{C}} 27.0\right)$ in the 1,2-diol acetonide (Scheme 1$)$. Therefore, the relative configuration of 2 was determined. Furthermore, the similar NMR data between 2 and aigialomycin F at stereogenic centers also supported the same relative stereochemistry of 2 as that of aigialomycin $\mathrm{F}$. The absolute configuration at $\mathrm{C}-\mathbf{1}^{\prime}$ of 2 was confirmed as $R$ by considering the same biosynthetic pathway for the known $\beta$-resorcylic acid lactones. ${ }^{11}$ Thus, the absolute configuration of 2 was deduced to be $1^{\prime} R, 2^{\prime} S, 4^{\prime} S, 5^{\prime} R, 6^{\prime} S$.

The molecular formula of aigialomycin I (3) was established as $\mathrm{C}_{19} \mathrm{H}_{26} \mathrm{O}_{7}$ with 7 degrees of unsaturation, determined by HRESIMS at $m / z[\mathrm{M}+\mathrm{H}]^{+} 367.1757$. The ${ }^{1} \mathrm{H}$ and ${ }^{13} \mathrm{C}$ NMR data of 3 showed similar structure with those of dihydrohypothemycin (8), ${ }^{13}$ except for the absence of one ketone carbon, and the presence of a methylene $\left(\delta_{\mathrm{H}} 1.76,2.07, \delta_{\mathrm{C}} 27.9\right)$ that was assigned at $\mathrm{C}-4^{\prime}$ by the ${ }^{1} \mathrm{H}-{ }^{1} \mathrm{H}$ COSY correlations of $\mathrm{H}-1^{\prime}-\mathrm{H}-2^{\prime}-$ $\mathrm{H}_{2}-3^{\prime}-\mathrm{H}_{2}-4^{\prime}-\mathrm{H}-5^{\prime}-\mathrm{H}-6^{\prime}-\mathrm{H}_{2}-7^{\prime}-\mathrm{H}_{2}-8^{\prime}$ and the HMBC correlations of $\mathrm{H}_{2}-4^{\prime}$ with C-2 $2^{\prime}, \mathrm{C}-3^{\prime}, \mathrm{C}-5^{\prime}$ and $\mathrm{C}-6^{\prime}$. Considering the chemical shifts of $\mathrm{C}-5^{\prime}\left(\delta_{\mathrm{C}} 71.2\right)$ and $\mathrm{C}-6^{\prime}\left(\delta_{\mathrm{C}} 69.0\right)$, the two hydroxyl moieties were attached at $\mathrm{C}-5^{\prime}$ and $\mathrm{C}-6^{\prime}$, respectively. The stereochemistry of $\mathrm{C}^{-} 5^{\prime}$ and $\mathrm{C}-6^{\prime}$ were assigned as $5^{\prime} R, 6^{\prime} S$ by

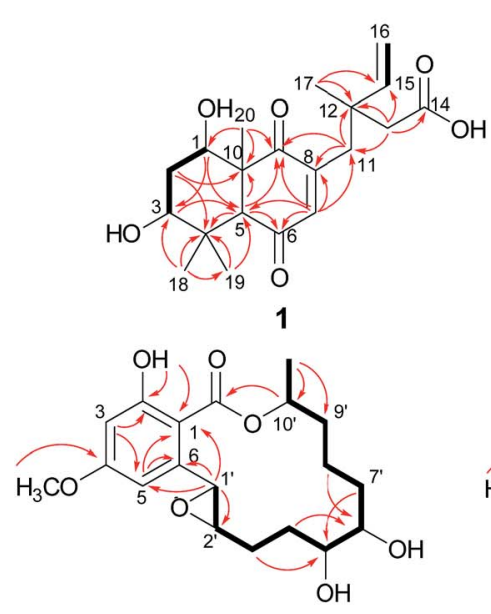

3

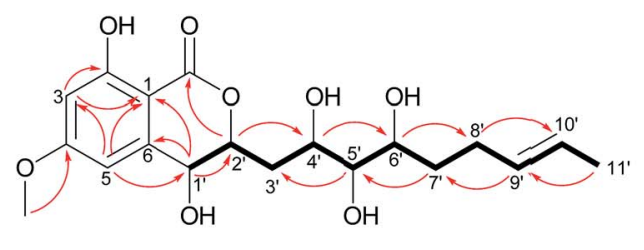

2

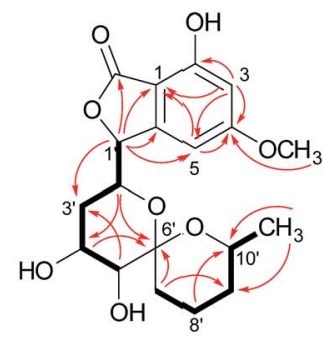

5
4

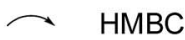

Fig. 2 Key ${ }^{1} \mathrm{H}-{ }^{1} \mathrm{H}$ COSY and $\mathrm{HMBC}$ correlations of compounds 1-5. 

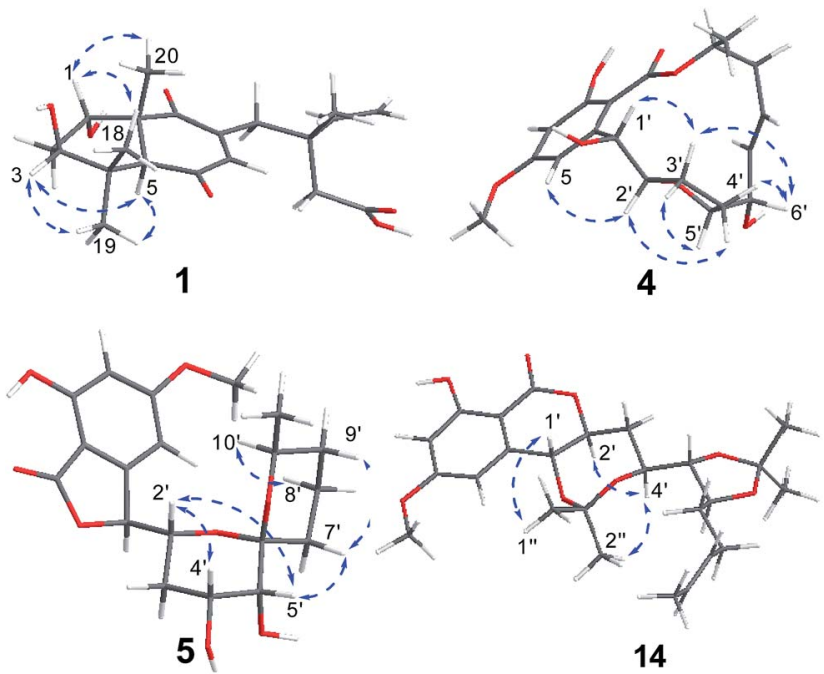

Fig. 3 Key ROESY correlations of compounds 1, 4-5 and 14.

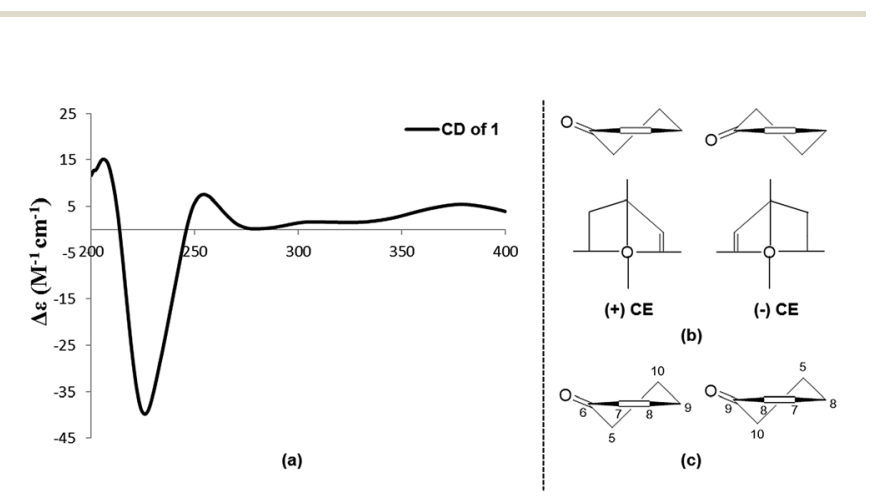

Fig. 4 (a) CD spectrum of 1. (b) Standard conformation of $\alpha, \beta-$ unsaturated cyclohexanone and its application of the octant rule. (c) The application of $\alpha, \beta$-unsaturated cyclohexanone octant rule in 1.

applying the Snatzke's method ${ }^{\mathbf{2 1}}$ base on an observed positive Cotton effect at $318 \mathrm{~nm}$ in the $\mathrm{Mo}_{4}(\mathrm{OAc})_{4}$-induced $\mathrm{CD}$ spectrum (Fig. 6). The absolute configurations of $\mathrm{C}-1^{\prime}, \mathrm{C}-2^{\prime}$ and $\mathrm{C}-10^{\prime}$ in 3 were deduced to be $1^{\prime} R, 2^{\prime} R, 10^{\prime} S$ by the similar negative Cotton effects around $264 \mathrm{~nm}$ and $307 \mathrm{~nm}$ with those of compound 9 (Fig. 5). Therefore, the absolute configuration of 3 was determined to be $1^{\prime} R, 2^{\prime} R, 5^{\prime} R, 6^{\prime} S, 10^{\prime} S$.

Paecilomycin $\mathrm{N}$ (4) was obtained as a white power. Its molecular formula was determined as $\mathrm{C}_{19} \mathrm{H}_{24} \mathrm{O}_{7}$ (8 degrees of unsaturation) on the basis of HRESIMS ion peak at $m / z[\mathrm{M}+\mathrm{H}]^{+}$ 407.2138. The structure of 4 was confirmed by analysis of 1D and 2D NMR spectra (Table 3). A trans-configuration between $\mathrm{H}^{-}$ $7^{\prime}$ and $\mathrm{H}-\mathrm{8}^{\prime}$ was determined on the basis of the larger coupling constant $\left(J_{7^{\prime}, 8^{\prime}}=15.7 \mathrm{~Hz}\right)$ in 4. In the ROESY spectrum, the correlations of $\mathrm{H}-1^{\prime}\left(\delta_{\mathrm{H}} 5.60\right)$ with $\mathrm{H}-3^{\prime} \beta\left(\delta_{\mathrm{H}} 2.02\right)$ as well as $\mathrm{H}-6^{\prime}$ $\left(\delta_{\mathrm{H}} 3.98\right)$ with $\mathrm{H}-3^{\prime} \beta$ and $\mathrm{H}-4^{\prime} \beta\left(\delta_{\mathrm{H}} 1.76\right)$ indicated that $\mathrm{H}-1^{\prime}, \mathrm{H}-$ $3^{\prime} \beta, \mathrm{H}-4^{\prime} \beta$, and $\mathrm{H}-6^{\prime}$ were on the same side. The correlations of $\mathrm{H}-2^{\prime}\left(\delta_{\mathrm{H}} 4.10\right)$ with $\mathrm{H}-4^{\prime} \alpha\left(\delta_{\mathrm{H}} 2.07\right)$, and $\mathrm{H}-3^{\prime} \alpha\left(\delta_{\mathrm{H}} 2.25\right)$ with $\mathrm{H}-5^{\prime}$ ( $\left.\delta_{\mathrm{H}} 4.15\right)$ placed $\mathrm{H}-2^{\prime}, \mathrm{H}-3^{\prime} \alpha, \mathrm{H}-4^{\prime} \alpha$ and $\mathrm{H}-5^{\prime}$ on the opposite side (Fig. 3). The absolute configuration of $\mathbf{4}$ was assigned as $1^{\prime} R, 2^{\prime} S, 5^{\prime} R, 6^{\prime} S, 10^{\prime} S$ by comparing the CD spectrum between 4 and 9 (Fig. 5).
Table $2{ }^{1} \mathrm{H}(500 \mathrm{MHz})$ and ${ }^{13} \mathrm{C}$ NMR $(125 \mathrm{MHz})$ data of 2 in DMSO- $d_{6}$

\begin{tabular}{|c|c|c|}
\hline No. & $\delta_{\mathrm{C}}$ & $\delta_{\mathrm{H}}($ mult. $J$ in $\mathrm{Hz})$ \\
\hline 1 & 100.1 & \\
\hline 2 & 163.1 & \\
\hline 3 & 100.0 & $6.48, \mathrm{~d}(2.4)$ \\
\hline 4 & 165.7 & \\
\hline 5 & 104.8 & $6.60, \mathrm{~d}(2.3)$ \\
\hline 6 & 145.1 & \\
\hline $1^{\prime}$ & 66.7 & $4.52, \mathrm{t}(6.6)$ \\
\hline $2^{\prime}$ & 80.3 & $4.60, \mathrm{~m}$ \\
\hline $3^{\prime}$ & 36.1 & $\begin{array}{l}1.90, \mathrm{~m} \\
1.69, \mathrm{t}(13.0)\end{array}$ \\
\hline $4^{\prime}$ & 65.9 & $3.71, \mathrm{~m}$ \\
\hline $5^{\prime}$ & 76.1 & $2.96, \operatorname{td}(7.7,2.1)$ \\
\hline $6^{\prime}$ & 68.7 & $3.64, \mathrm{~m}$ \\
\hline $7^{\prime}$ & 33.5 & $\begin{array}{l}1.47, \mathrm{~m} \\
1.40, \mathrm{~m}\end{array}$ \\
\hline $8^{\prime}$ & 28.7 & $\begin{array}{l}2.05, \mathrm{~m} \\
1.96, \mathrm{~m}\end{array}$ \\
\hline $9^{\prime}$ & 131.5 & $5.42, \mathrm{~m}$ \\
\hline $10^{\prime}$ & 124.2 & $5.40, \mathrm{~m}$ \\
\hline $11^{\prime}$ & 17.8 & $1.60, \mathrm{~d}(4.8)$ \\
\hline$-\mathrm{COO}-$ & 168.1 & \\
\hline $2-\mathrm{OH}$ & & $11.12, \mathrm{~s}$ \\
\hline $4-\mathrm{OCH}_{3}$ & 55.8 & $3.83, \mathrm{~s}$ \\
\hline $1^{\prime}-\mathrm{OH}$ & & $6.04, \mathrm{~d}(6.2)$ \\
\hline $4^{\prime}-\mathrm{OH}$ & & $4.76, \mathrm{~d}(6.4)$ \\
\hline $5^{\prime}-\mathrm{OH}$ & & $4.29, \mathrm{~d}(7.4)$ \\
\hline $6^{\prime}-\mathrm{OH}$ & & $4.05, \mathrm{~d}(7.0)$ \\
\hline
\end{tabular}

$4^{\prime} R, 5^{\prime} R$-Dihydroaigialospirol (5) was isolated as a colorless solid with the molecular formula $\mathrm{C}_{19} \mathrm{H}_{24} \mathrm{O}_{8}$ (7 degrees of unsaturation). Careful analysis of 1D and 2D NMR data (Table 3), particularly ${ }^{1} \mathrm{H}^{-1} \mathrm{H}$ COSY and HMBC revealed the same planar structure with the known compound $7^{\prime}, 8^{\prime}$-dihydroaigialospirol (6) (Fig. 2). The smaller coupling constant $\left(J_{4^{\prime}, 5^{\prime}}=3.5 \mathrm{~Hz}\right.$ ) between $\mathrm{H}-4^{\prime}$ and $\mathrm{H}-5^{\prime}$ in 5 implied a syn configuration. The NOE correlations of $\mathrm{H}-2^{\prime}\left(\delta_{\mathrm{H}} 4.01\right)$ with $\mathrm{H}-4^{\prime}\left(\delta_{\mathrm{H}} 3.98\right)$ and $\mathrm{H}-5^{\prime}\left(\delta_{\mathrm{H}}\right.$ 3.49) placed these protons on the same face of the rings. $1 \mathrm{D}$ NOE correlations of $\mathrm{H}-10^{\prime}$ to $\mathrm{H}-2^{\prime}$ and $\mathrm{H}-5$ revealed their proximity in space, and the relative configuration of the spiroketal carbon C$6^{\prime}$ also was determined meanwhile. In the previous report, the absolute configuration of compound $\mathbf{6}$ has been determined by chemical derivation and X-ray analysis. The identical negative Cotton effect at 216 and $284 \mathrm{~nm}$, and positive Cotton effect at $240 \mathrm{~nm}$ between 5 and the co-isolated known compound 6 (Fig. 7), combined with the almost same chemical shifts and coupling constant of $\mathrm{H}-1^{\prime}$ and $\mathrm{H}-2^{\prime}$ between 5 and $\mathbf{6}$, implied the $1^{\prime} S, 2^{\prime} R$ configuration at $\mathrm{C}-1^{\prime}$ and $\mathrm{C}-2^{\prime}$. Thus, the absolute configuration of 5 was determined as $1^{\prime} S, 2^{\prime} R, 4^{\prime} R, 5^{\prime} R, 6^{\prime} R, 10^{\prime} S$.

Compounds 1-13 were tested for their cytotoxic activities against A549, K562 and ASPC cell lines using MTT method. ${ }^{22}$ Only compound 7 showed moderate cytotoxicity against A549 cell line with $\mathrm{IC}_{50}$ values of $44.5 \mu \mathrm{M} \pm 3.1$ (positive control: $\mathrm{IC}_{50}$ of cisplatin against A549 was $25.60 \mu \mathrm{M} \pm 2.8$ ). None of them exhibited cytotoxicities against K562 and ASPC at the concentration of $100 \mu \mathrm{M}$.

In conclusion, the investigation of the fungicolous fungus $H$. subiculosus obtained from Polyporus versicolor resulted in the 


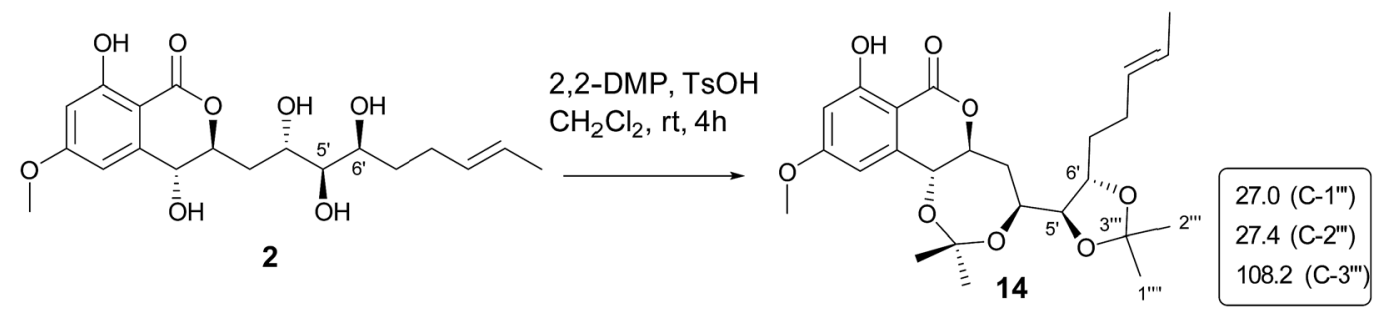

Scheme 1 Preparation of acetonide derivatives of 14 and ${ }^{13} \mathrm{C}$ NMR signals of acetonide carbon atoms; 2,2-DMP = 2,2-dimethoxypropane, $\mathrm{TsOH}=$ para-toluenesulfonic acid.

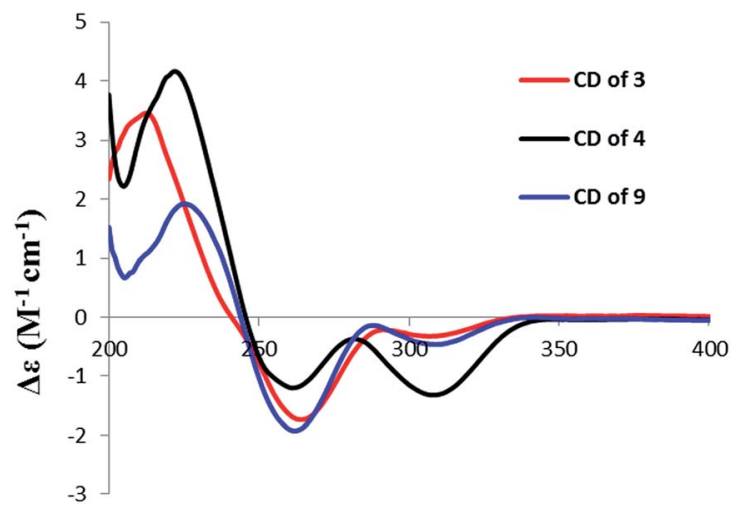

Fig. 5 CD spectrum of 3,4 , and 9 .

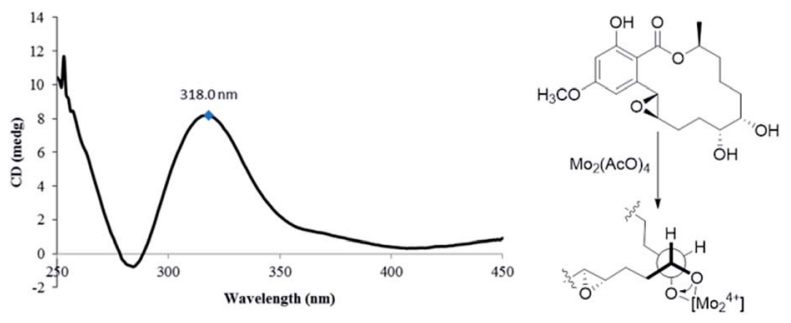

Fig. $6 \mathrm{CD}$ spectrum of Mo-complex of 3 with $\mathrm{MO}_{2}(\mathrm{AcO})_{4}$

isolation and identification of five new compounds and eight known compounds. Compound $\mathbf{1}$ is a ring cleavage pimarane diterpene with new structural type. Compounds $2-5$ are new $\beta$ resorcylic acid lactone derivatives. The cytotoxic activities for these compounds against a small panel of tumor cell lines were evaluated. The discovery of compounds 1-5 expands the resources for natural products.

\section{Experimental section}

\section{General experimental procedures}

The NMR spectroscopic data were measured on a Bruker Avance-500 spectrometer. UV and IR spectroscopic data were recorded on a Thermo Genesys-10S UV/Vis and Nicolet IS5FT-IR spectrophotometer, respectively. HRTOFMS data were obtained with an Agilent Accurate-Mass-Q-TOF LC/MS 6520 spectrometer. CD spectra were measured with a Chirascan circular dichroism spectrometer (Applied Photophysics, Surrey, UK).
TLC were performed on plates precoated with Silica gel $\mathrm{HSGF}_{254}$ and the spots were detected under UV lights or by heating after spraying with $10 \% \mathrm{H}_{2} \mathrm{SO}_{4}$. Silica gel (200-300 mesh, Qingdao Haiyang Chemical Co., Ltd., People's Republic of China), and Sephadex LH-20 (Amersham Biosciences) were used for column chromatography. Semi-preparative HPLC was performed with an Waters 2489 HPLC system using an octadecylsilyl (ODS) column (YMC-Pack, ODS-A, $10 \times 250 \mathrm{~mm}, 5 \mu \mathrm{m}$ ).

\section{Fungal material}

The fungal H. subiculosus was isolated from Polyporus versicolor. The strain was identified based on combined data of morphology, anatomy, culture characteristics, type of substrate, and the DNA sequences of ITS1-5.8S-ITS2, RPB2 and TEF regions.

\section{Extraction and isolation}

H. subiculosus was cultured on PDB-agar plates at $25{ }^{\circ} \mathrm{C}$ for 7 days. Seed culture Agar plugs were inoculated into a $250 \mathrm{~mL}$ Erlenmeyer flask containing $100 \mathrm{~mL}$ PDB medium cultured at $25{ }^{\circ} \mathrm{C}$ for 10 days on a rotary shaker at $180 \mathrm{rpm}$. Mass scale fermentation was carried out in $20 \times 500 \mathrm{~mL}$ Fernbach culture flasks each containing $80 \mathrm{~g}$ of rice and $100 \mathrm{~mL}$ of distilled water. Each flask was inoculated with $5 \mathrm{~mL}$ of seed culture medium and incubated at $25{ }^{\circ} \mathrm{C}$ for 40 days in dark. After 40 days, the fermentated rice sample was harvested and extracted using EtOAc $(3 \times 10 \mathrm{~L})$, and $14 \mathrm{~g}$ crude extract was obtained by evaporating solvent under vaccum.

The crude extract was subjected to a silica gel column eluted with petroleum ether-EtOAc in a gradient eluent $(\mathrm{v} / \mathrm{v}, 100: 0$, $50: 1,20: 1,10: 1,5: 1)$, followed by $\mathrm{CH}_{2} \mathrm{Cl}_{2}-\mathrm{MeOH}(\mathrm{v} / \mathrm{v}$, $100: 0,100: 1,80: 1,50: 1,20: 1,10: 1,0: 100)$ to obtain 16 fractions (fr.1-fr.16) on the basis of TLC. The fr.9 (2.5 g) was separated by ODS CC using a gradient of $\mathrm{MeOH}-\mathrm{H}_{2} \mathrm{O}(25-100 \%)$ to afford 19 subfractions (fr.9.1-fr.9.19). The fr.9.7 was further purified by RP-HPLC ( $43 \% \mathrm{MeOH}$ in $\mathrm{H}_{2} \mathrm{O}$ for $30 \mathrm{~min}$ ) to obtain 4 (3.5 $\mathrm{mg}, t_{\mathrm{R}}=27.5 \mathrm{~min}$ ). The fr.9.9 was further purified by Sephadex LH-20 CC eluted with $100 \% \mathrm{MeOH}$ to afford 6 (91.5 $\mathrm{mg})$. The fr.9.8 was further separated by Sephadex LH-20 CC eluted with $100 \% \mathrm{MeOH}$, followed by RP-HPLC ( $40 \% \mathrm{MeOH}$ for $55 \mathrm{~min})$ to afford $12\left(15.7, t_{\mathrm{R}}=51.5 \mathrm{~min}\right), 13\left(16.2, t_{\mathrm{R}}=52.8\right.$ min). The fr.9.19 was further purified by semipreparative reversed-phase (RP) HPLC (YMC-ODS C18 column; $5 \mu \mathrm{m}$; $9.4 \times$ $250 \mathrm{~mm} ; 60 \% \mathrm{MeOH}$ in $\mathrm{H}_{2} \mathrm{O}$ for $\left.35 \mathrm{~min}\right)$ to afford $2\left(3.8 \mathrm{mg}, t_{\mathrm{R}}=\right.$ 
Table $3{ }^{1} \mathrm{H}(500 \mathrm{MHz})$ and ${ }^{13} \mathrm{C}$ NMR $(125 \mathrm{MHz})$ data of 3-5 in $\mathrm{CDCl}_{3}$

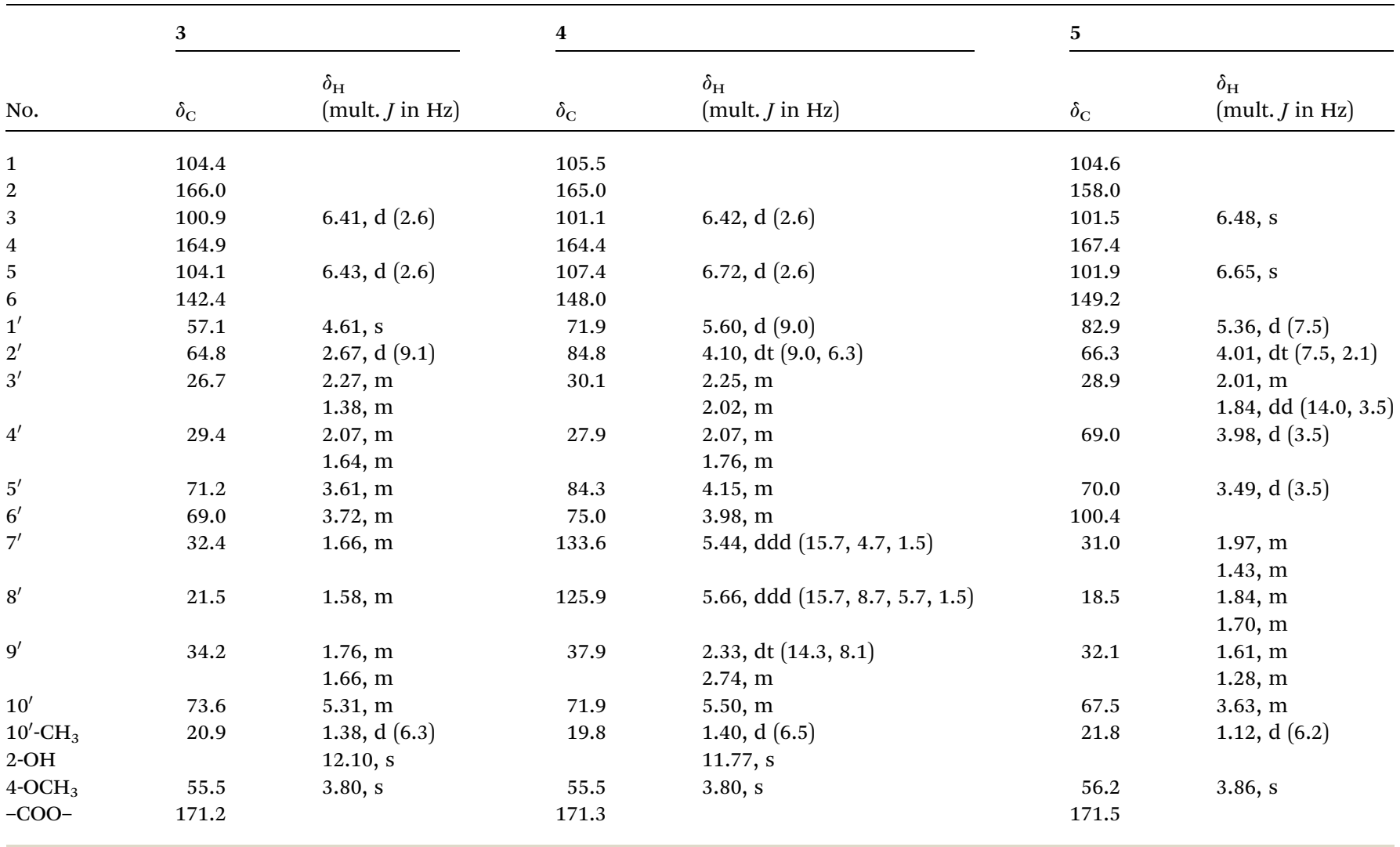

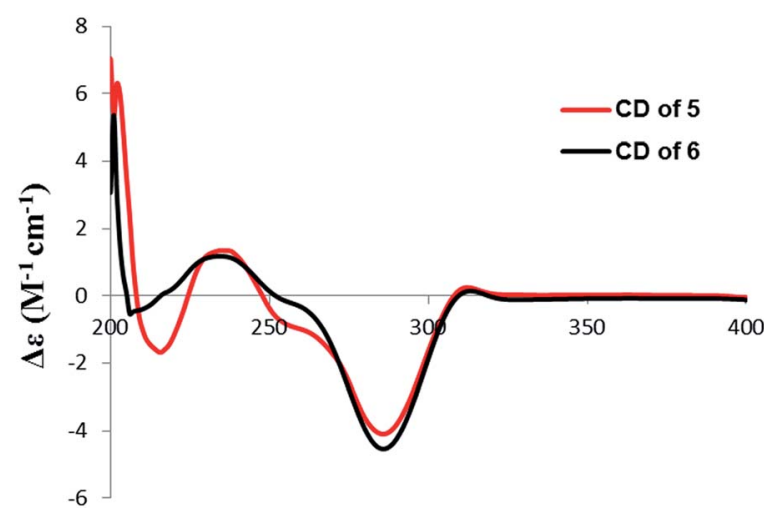

Fig. 7 CD spectrum of 5 and 6 .

$32.2 \mathrm{~min}), 7\left(37.8 \mathrm{mg}, t_{\mathrm{R}}=15.9 \mathrm{~min}\right), 8\left(43.7 \mathrm{mg}, t_{\mathrm{R}}=28.8 \mathrm{~min}\right)$. The fr.11 ( $2.8 \mathrm{~g}$ ) was subjected to ODS CC eluted with a gradient of $\mathrm{MeOH}-\mathrm{H}_{2} \mathrm{O}(10-100 \%)$ further separated by Sephadex LH-20 CC eluted with $100 \% \mathrm{MeOH}$, followed by RP-HPLC (58\% MeOH for $55 \mathrm{~min})$ to afford $1\left(2.3 \mathrm{mg}, t_{\mathrm{R}}=19.0 \mathrm{~min}\right), 5\left(2.8 \mathrm{mg}, t_{\mathrm{R}}=\right.$ $24.3 \mathrm{~min}), 9\left(4.5 \mathrm{mg}, t_{\mathrm{R}}=28.0 \mathrm{~min}\right), 6\left(42.0 \mathrm{mg}, t_{\mathrm{R}}=50.8 \mathrm{~min}\right)$. The fr.12 (1.1 g) was subjected to ODS CC eluted with $\mathrm{MeOH}-$ $\mathrm{H}_{2} \mathrm{O}$ in a gradient eluent (10-100\%), followed by RP-HPLC (50\% $\mathrm{MeOH}$ for $40 \mathrm{~min})$ to obtain $10\left(5.2 \mathrm{mg}, t_{\mathrm{R}}=24.7 \mathrm{~min}\right), 3$ (2.3 mg, $\left.t_{\mathrm{R}}=33.5 \mathrm{~min}\right), 11\left(20.0 \mathrm{mg}, t_{\mathrm{R}}=36.0 \mathrm{~min}\right)$.

Subiculosin A (1). $\mathrm{C}_{20} \mathrm{H}_{28} \mathrm{O}_{6},[\alpha]_{\mathrm{D}}^{20.0}+55.60\left(c 0.13, \mathrm{CH}_{2} \mathrm{Cl}_{2}\right.$ ); $\mathrm{UV}(\mathrm{MeOH}) \lambda_{\max }(\log \varepsilon) 245(4.12) \mathrm{nm} ; \mathrm{CD}\left(c 9.5 \times 10^{-4} \mathrm{M}\right.$,
$\mathrm{MeOH}) \lambda_{\max }(\Delta \varepsilon) 226(-39.7), 254(+7.5), 380(+5.4) ;$ IR (neat) $\nu_{\max } 3419,2930,1677,1378,1203,1054,997 \mathrm{~cm}^{-1} ;{ }^{1} \mathrm{H}$ NMR (500 $\mathrm{MHz}$, acetone- $\left.d_{6}\right)$ and ${ }^{13} \mathrm{C}$ NMR $\left(125 \mathrm{MHz}\right.$, acetone- $\left.d_{6}\right)$ data, see Table 1; positive HRESIMS $m / z 365.1962[\mathrm{M}+\mathrm{H}]^{+}$(calcd for $\left.\mathrm{C}_{20} \mathrm{H}_{29} \mathrm{O}_{6}, 365.1964\right)$.

Aigialomycin $\mathbf{H}$ (2). Colorless solid; $[\alpha]_{\mathrm{D}}^{20.0}-13.33$ (c 0.03, $\mathrm{CH}_{2} \mathrm{Cl}_{2}$ ); UV (MeOH) $\lambda_{\max }(\log \varepsilon) 212$ (4.40), 268 (4.17), 303 (3.89) nm; IR (neat) $\nu_{\max } 2926,1681,1380,1210,1058,1034$, $706 \mathrm{~cm}^{-1} ;{ }^{1} \mathrm{H}$ NMR (500 MHz, DMSO- $d_{6}$ ) and ${ }^{13} \mathrm{C}$ NMR (125 MHz, DMSO- $d_{6}$ ) data, see Table 2; positive HRESIMS $\mathrm{m} / \mathrm{z}$ 383.1704 [M + H] $]^{+}$(calcd for $\mathrm{C}_{19} \mathrm{H}_{27} \mathrm{O}_{8}, 383.1706$ ).

Aigialomycin I (3). Colorless solid; $[\alpha]_{\mathrm{D}}^{20.0}-1.54$ (c 0.12, $\left.\mathrm{MeOH} / \mathrm{CH}_{2} \mathrm{Cl}_{2}=1: 1\right) ; \mathrm{UV}(\mathrm{MeOH}) \lambda_{\max }(\log \varepsilon) 220$ (4.59), 264 (4.28), 305 (4.01) nm; CD $\left(c 5.5 \times 10^{-4} \mathrm{M}, \mathrm{MeOH}\right) \lambda_{\max }(\Delta \varepsilon) 212$ (+3.4), $264(-1.7), 307(-0.3)$; IR (neat) $\nu_{\max } 3418,1647,1613$, 1357, 1318, 1257, 1205, 1160, $1111 \mathrm{~cm}^{-1}$; ${ }^{1} \mathrm{H}$ NMR $(500 \mathrm{MHz}$, $\mathrm{CDCl}_{3}$ ) and ${ }^{13} \mathrm{C} \mathrm{NMR}\left(125 \mathrm{MHz}, \mathrm{CDCl}_{3}\right)$ data, see Table 3; positive HRESIMS $m / z$ 367.1757 $[\mathrm{M}+\mathrm{H}]^{+}$(calcd for $\mathrm{C}_{19} \mathrm{H}_{27} \mathrm{O}_{7}$, 367.1757).

Paecilomycin N (4). White powder; $[\alpha]_{\mathrm{D}}^{20.0}-15.29$ (c 0.34 , $\mathrm{CH}_{2} \mathrm{Cl}_{2}$ ); UV (MeOH) $\lambda_{\text {max }}(\log \varepsilon) 220$ (4.63), 263 (4.34), 303 (3.99) $\mathrm{nm} ; \mathrm{CD}\left(c 5.5 \times 10^{-4} \mathrm{M}, \mathrm{MeOH}\right) \lambda_{\max }(\Delta \varepsilon) 222(+4.2), 260$ $(-1.2), 308$ (-1.3); IR (neat) $\nu_{\max } 3393,1645,1613,1254,1160$, $1037 \mathrm{~cm}^{-1} ;{ }^{1} \mathrm{H}$ NMR $\left(500 \mathrm{MHz}, \mathrm{CDCl}_{3}\right)$ and ${ }^{13} \mathrm{C}$ NMR $(125 \mathrm{MHz}$, $\mathrm{CDCl}_{3}$ ) data, see Table 3; positive HRESIMS $m / z$ 365.1601 [M + $\mathrm{H}]^{+}$(calcd for $\mathrm{C}_{19} \mathrm{H}_{25} \mathrm{O}_{7}, 365.1600$ ).

$\mathbf{4}^{\prime} \boldsymbol{R}, \mathbf{5}^{\prime} \boldsymbol{R}$-Dihydroaigialospirol (5). Colorless solid; $[\alpha]_{\mathrm{D}}^{20.0}+14.19\left(c 0.08, \mathrm{CH}_{2} \mathrm{Cl}_{2}\right) ; \mathrm{UV}(\mathrm{MeOH}) \lambda_{\max }(\log \varepsilon) 212(4.47)$, 
256 (4.21), $291(3.80) \mathrm{nm}$; CD $\left(c 8.0 \times 10^{-4} \mathrm{M}, \mathrm{MeOH}\right) \lambda_{\max }(\Delta \varepsilon)$ $216(-1.7), 240(+1.4), 282(-4.1)$; IR (neat) $\nu_{\max } 3420,1742$, 1613, 1217, 1157, $1069 \mathrm{~cm}^{-1} ;{ }^{1} \mathrm{H}$ NMR (500 MHz, $\left.\mathrm{CDCl}_{3}\right)$ and ${ }^{13} \mathrm{C}$ NMR (125 MHz, $\mathrm{CDCl}_{3}$ ) data, see Table 3; HRESIMS $\mathrm{m} / \mathrm{z}$ $381.1547[\mathrm{M}+\mathrm{H}]^{+}$(calcd for $\mathrm{C}_{19} \mathrm{H}_{25} \mathrm{O}_{8}, 381.1549$ ).

Compound 14. Colorless solid; ${ }^{1} \mathrm{H}$ NMR (500 MHz, DMSO- $d_{6}$ ) $\delta 6.51(1 \mathrm{H}, \mathrm{d}, J=2.4, \mathrm{H}-3), 6.48(1 \mathrm{H}, \mathrm{d}, J=2.4, \mathrm{H}-5), 5.44(2 \mathrm{H}, \mathrm{m}$, H-9', H-10'), 5.05 (1H, d, $\left.J=10.6, \mathrm{H}^{\prime} 1^{\prime}\right), 4.45$ (1H, td, $J=10.6$, 5.6, H-2') $3.90\left(1 \mathrm{H}, \mathrm{m}, \mathrm{H}-4^{\prime}\right), 3.87$ (1H, m, H-6 $)$, 3.83 (3H, s, 4$\left.\mathrm{OCH}_{3}\right), 3.56\left(1 \mathrm{H}, \mathrm{t}, J=7.1, \mathrm{H}-5^{\prime}\right), 2.30(1 \mathrm{H}, \mathrm{dd}, J=12.8,5.5, \mathrm{H}-$ $\left.3^{\prime} \alpha\right), 2.11\left(1 \mathrm{H}, \mathrm{m}, \mathrm{H}-8^{\prime}\right), 2.02\left(1 \mathrm{H}, \mathrm{m}, \mathrm{H}-8^{\prime}\right), 1.72\left(1 \mathrm{H}, \mathrm{m}, \mathrm{H}-7^{\prime}\right)$, $1.66\left(1 \mathrm{H}, \mathrm{m}, \mathrm{H}-3^{\prime} \beta\right), 1.61\left(3 \mathrm{H}, \mathrm{d}, J=2.1, \mathrm{H}-11^{\prime}\right), 1.54(1 \mathrm{H}, \mathrm{m}, \mathrm{H}-$ $\left.7^{\prime}\right), 1.42\left(3 \mathrm{H}, \mathrm{s}, \mathrm{H}-1^{\prime \prime}\right), 1.39\left(3 \mathrm{H}, \mathrm{s}, \mathrm{H}-2^{\prime \prime}\right), 1.33\left(3 \mathrm{H}, \mathrm{s}, \mathrm{H}-1^{\prime \prime \prime}\right), 1.32$ $\left(3 \mathrm{H}, \mathrm{s}, \mathrm{H}-2^{\prime \prime \prime}\right) ;{ }^{13} \mathrm{C}$ NMR (125 MHz, DMSO- $\left.d_{6}\right) \delta 167.9$ (C, C-12), 166.0 (C, C-4), 163.4 (C, C-2), 143.8 (C, C-6), 130.8 (CH, C-9'), $124.9\left(\mathrm{CH}, \mathrm{C}-10^{\prime}\right), 108.2$ (C, C-3"') 103.8 (CH, C-5), 101.7 (C, C3"), 99.8 (C, C-1), 99.7 (CH, C-3), $81.6\left(\mathrm{CH}, \mathrm{C}-5^{\prime}\right), 78.4\left(\mathrm{CH}, \mathrm{C}-2^{\prime}\right)$, $78.0\left(\mathrm{CH}, \mathrm{C}-4^{\prime}\right), 67.9\left(\mathrm{CH}, \mathrm{C}-6^{\prime}\right), 66.8\left(\mathrm{CH}, \mathrm{C}-1^{\prime}\right), 55.9\left(\mathrm{CH}_{3}, 4-\right.$ $\left.\mathrm{OCH}_{3}\right), 36.8\left(\mathrm{CH}_{2}, \mathrm{C}-7^{\prime}\right), 33.9\left(\mathrm{CH}_{2}, \mathrm{C}-3^{\prime}\right), 28.7\left(\mathrm{CH}_{2}, \mathrm{C}-8^{\prime}\right), 27.4$ $\left(\mathrm{CH}_{3}, \mathrm{C}-1^{\prime \prime \prime}\right), 27.0\left(\mathrm{CH}_{3}, \mathrm{C}-2^{\prime \prime \prime}\right), 24.5\left(\mathrm{CH}_{3}, \mathrm{C}-1^{\prime \prime}\right), 24.5\left(\mathrm{CH}_{3}, \mathrm{C}-2^{\prime \prime}\right)$, $17.8\left(\mathrm{CH}_{3}, \mathrm{C}-11^{\prime}\right)$. Positive HRESIMS $m / z$ 463.2335 $[\mathrm{M}+\mathrm{H}]^{+}$ (calcd for $\mathrm{C}_{25} \mathrm{H}_{35} \mathrm{O}_{8}, 463.2332$ ).

\section{Synthesis of the acetonide derivative 14}

Compound $\mathbf{1 4}$ was synthesized from compound 2 by using a published method. ${ }^{11}$ To a suspension of $2(2.0 \mathrm{mg})$ in 2,2dimethoxypropane $(0.5 \mathrm{~mL})$ was added $\mathrm{TsOH}(0.5 \mathrm{mg})$. The mixture was stirred at room temperature for $4 \mathrm{~h}$, then reaction mixture was diluted with EtOAc and washed with saturated $\mathrm{NaHCO}_{3}$. The organic layer was concentrated under reduced pressure to leave a colorless solid, which was purified by RPHPLC using $\mathrm{MeOH}-\mathrm{H}_{2} \mathrm{O}(95: 5)$ to afford 14 (1.0 mg).

\section{Determination of the absolute configuration at $5^{\prime}, 6^{\prime}$-diol moiety by Snatzke's method}

A sample of $3(0.5 \mathrm{mg})$ was dissolved in a dry stock solution of the dimolybdenum tetraacetate $\left[\mathrm{Mo}_{2}(\mathrm{OAc})_{4}\right](0.7 \mathrm{mg})$ in DMSO $(1 \mathrm{~mL})$ and the CD spectrum was recorded immediately after mixing. The CD spectrum was recorded every $10 \mathrm{~min}$ until a stationary spectrum was reached (30 min after mixing). The inherent CD from 3 was subtracted to give the induced CD of the complex. The observed sign of the diagnostic band at $318 \mathrm{~nm}$ (band IV) was correlated to the absolute configuration at $5^{\prime}, 6^{\prime}$-diol moiety.

\section{Cytotoxicity}

The cytotoxicities of compounds 1-13 against the K562, A549 and $\mathrm{H} 460$ cell lines were investigated by using the MTT method as previously reported..$^{22}$

\section{Conflicts of interest}

There are no conflicts to declare.

\section{Acknowledgements}

This work was supported in part by the National Natural Science Foundation of China (81673334).

\section{Notes and references}

1 P. Jeffries, Can. J. Bot., 1995, 73, 1284-1290.

2 R. F. Angawi, D. C. Swenson, J. B. Gloer and D. T. Wicklow, J. Nat. Prod., 2003, 66, 1259-1262.

3 C. Li, J. B. Gloer, D. T. Wicklow and P. F. Dowd, Org. Lett., 2002, 18, 3095-3098.

4 L. E. Schmidt, J. B. Gloer and D. T. Wicklow, J. Nat. Prod., 2007, 70, 1317-1320.

5 S. H. Shim, J. Baltrusaitis, J. B. Gloer and D. T. Wicklow, J. Nat. Prod., 2011, 74, 395-401.

6 A. A. Sy, D. C. Swenson, J. B. Gloer and D. T. Wicklow, J. Nat. Prod., 2008, 71, 415-419.

7 J. L. C. Wright, A. G. Mclnnes, D. G. Smith and L. C. Vining, Can. J. Chem., 1970, 48, 2720.

8 J. L. Wee, K. Sundermann, P. Licari and J. Galazzo, J. Nat. Prod., 2006, 69, 1456-1459.

9 K. Dornberger, W. Ihn, M. Ritzau, U. Grafe, B. Schlegel, W. F. Fleck and J. W. Metzger, J. Antibiot., 1995, 48, 977-989.

10 G. M. Hatfield and D. E. Slagle, Lloydia, 1973, 36, 354-356.

11 M. Isaka, A. Yangchum, S. Intamas, K. Kocharin, E. B. G. Jones, P. Kongsaeree and S. Prabpai, Tetrahedron, 2009, 65, 4396-4403.

12 M. Nair and S. T. Carey, Tetrahedron Lett., 1980, 21, 20112012.

13 M. Isaka, C. Suyarnsestakorn and M. Tanticharoen, J. Org. Chem., 2002, 675, 1561-1566.

14 L. X. Xu, P. Wu, H. H. Wei, J. H. Xue, X. P. Hu and X. Y. Wei, Tetrahedron Lett., 2013, 5421, 2648-2650.

15 K. Matsunami, H. Otsuka and Y. Takeda, Chem. Pharm. Bull., 2010, 58, 438-441.

16 R. D. Burnet and D. N. Kirk, J. Chem. Soc., Perkin Trans. 1, 1981, 1460-1468.

17 Y. Sun, L. Tian, J. Huang, H. Y. Ma, Z. Zheng, A. L. Lv, K. Yasukawa and Y. H. Pei, Org. Lett., 2008, 10, 393-396.

18 G. Dana and H. Danechpajouh, Bull. Soc. Chim. Fr., 1980, 395-399.

19 M. Bock, K. Buntin, R. Muller and A. Kirschning, Angew. Chem., Int. Ed., 2008, 47, 2308-2311.

20 S. Hoshino, M. Okada, T. Awakawa, S. Asamizu, H. Onaka and I. Abe, Org. Lett., 2017, 19, 4992-4995.

21 J. Frelek, Z. Pakulski and A. Zamojski, Tetrahedron: Asymmetry, 1996, 7, 1363-1372.

22 Y. Q. Wang, L. Bao, D. L. Liu, X. L. Yang, S. F. Li, H. Gao, X. S. Yao, H. A. Wen and H. W. Liu, Tetrahedron, 2012, 68, 3012-3018. 